\title{
Effect of Organic and Inorganic Sources of Nitrogen on Plant Growth, Bulb Characteristics and Yield of Tuberose (Polianthes tuberose L.) cv. Prajwal
}

\author{
Sukirti Mohanty ${ }^{1}$, Manas Ranjan Nath ${ }^{2}$ and Sidhhath Kumar Palai ${ }^{2}$ \\ ${ }^{1}$ Institute of Agricultural Sciences, SOADU, Bhubaneswar, India \\ ${ }^{2}$ Floriculturist, BTCC, OUAT, Bhubaneswar, India \\ *Corresponding author
}

\section{A B S T R A C T}

\section{Keywords}

Tuberose

(Polianthestuberosa

L.) cv. Prajwal, cut

flower, organic

Nitrogen sources,

inorganic soil

ammendments

Article Info

Accepted:

12 February 2020

Available Online:

10 March 2020
An experiment was conducted to elucidate the effectiveness of different soil organic amendments and chemical fertilizers on growth and yield of tuberose. the result of the study revealed that among all the organic manures and their combinations with inorganic fertilisers, the best results were recorded in $\mathrm{T}_{9}[75 \% \mathrm{~N}$ (Urea) $+25 \% \mathrm{~N}$ (Mustard oil cake)] with respect to vegetative parameters (plant height, number of leaves per plant, leaf length); Yield attributing parameters (maximum flower number and minimum days taken for the opening of first flower from planting, including number of spike per plot, spike length) compared to other treatments. Bulb parameters, including bulb length, bulb weight and circumference of the bulb showed best result in $\mathrm{T}_{6}[50 \% \mathrm{~N}$ (Urea) $+50 \% \mathrm{~N}$ (Mustard oil cake)] compared to other treatments.

\section{Introduction}

Tuberose (Polianthes tuberosa L.) is one of the most important tropical ornamental bulbous flowering plants cultivated for production of long lasting flower spikes. It is popularly known as Rajanigandha or Nishigandha, which is an important commercial cut as well as loose flower crop due to pleasant fragrance, longer vaselife of spikes, higher returns and wide adaptability to varied climatic and soil condition. The quality of cut flowers is greatly influenced by climatic, geographical and nutritional factors.

Tuberose requires high nutrient for proper growth and development and to achieve the escalating target of good quality tuberose production, proper nutrient application is the prime need. Among the fertilizers, nitrogen plays a crucial role in plant growth and development of tuberose which influences the vegetative growth like number of leaves, plant height, stem diameter, spike length etc. In 
addition to chemical fertilizer the use of green manures and other organic matter can improve soil structure, soil health by enhancing the nutrient exchange capacity and that is why interests have been raising in organic farming (Mitra, 2010).But complete organic way to provide required Nitrogen to the plant is not an easy task. So the experiment was conducted to study the effect of different sources of nitrogenous fertilizer in addition with the inorganic and organic sources on vegetative character and yield.

Tripathi et al., (2012) opined that tuberose cv. Single with $75 \%$ recommended dose of NPK +500 q FYM per ha +250 q vermicompost per ha produced highest number of shoot per clump (18.95), number of leaves per shoot (19.44) and bulb yield (53.10 tonnes per ha). Maximum spike yield (205030.71 spikes $\mathrm{ha}^{-1}$ ), number of bulbs per clump (7.767) and weight of bulb per clump (132.63 g) in the same treatment.

Habib et al., (2015) reported that maximum plant height, number of leaves per plant, spike length, rachis length and yield of spikes per hectare were obtained with the application of $10 \mathrm{t}$ vermi-compost along with 50\% recommended dose of fertilizer (RDF).

\section{Materials and Methods}

The field experiment was conducted during May 2016 to May 2017 at Biotechnology cum Tissue Culture Center (BTCC), Orissa University of Agriculture and Technology, Bhubaneswar, Odisha. The experiment is formulated with eleven treatments using FYM, vermicompost, mustard oil cake alone and with the combination of inorganic fertiliser and three replications. Prajwal variety of tuberose was used to examine by using Randomised Block Design (RBD) for its response towards inorganic and organic source of $\mathrm{N}$ and the data were recorded on various parameters during vegetative and flowering stage. Three plants were selected at random and tagged in each treatment and replication. The mean value of the data was observed and processed.

\begin{tabular}{|c|c|}
\hline Treatments & Description \\
\hline $\mathbf{T}_{\mathbf{0}}$ & Control plot \\
\hline T1 & $100 \%$ N (FYM) \\
\hline T2 & $100 \% \mathrm{~N}$ (Vermicompost) \\
\hline T3 & $100 \% \mathrm{~N}$ (Mustard oil cake) \\
\hline T4 & $50 \% \mathrm{~N}($ Urea $)+50 \% \mathrm{~N}(\mathrm{FYM})$ \\
\hline T5 & $\begin{array}{l}50 \% \mathrm{~N} \text { (Urea) }+50 \% \mathrm{~N} \\
\text { (Vermicompost) }\end{array}$ \\
\hline T6 & $\begin{array}{l}50 \% \mathrm{~N}(\text { Urea })+50 \% \mathrm{~N} \\
\text { (Mustard oil cake) }\end{array}$ \\
\hline T7 & $75 \% \mathrm{~N}($ Urea $)+25 \% \mathrm{~N}(\mathrm{FYM})$ \\
\hline T8 & $\begin{array}{l}75 \% \mathrm{~N} \text { (Urea) }+25 \% \mathrm{~N} \\
\text { (Vermicompost) }\end{array}$ \\
\hline T9 & $\begin{array}{l}75 \% \mathrm{~N} \text { (Urea) }+25 \% \mathrm{~N} \\
\text { (Mustard oil cake) }\end{array}$ \\
\hline T10 & $100 \%$ N (Urea) \\
\hline
\end{tabular}

The height of the plant was measured from the ground level till the leaves started separating from the main stem. Observations were taken at first spike development stage. Similarly total number of matured leaves from tagged plants were counted and the mean value was recorded. Length of the leaf was measured from the base of the leaf to tip.

Days taken for emergence of spike were recorded by counting the days from the date of planting to the emergence of spike in each net plot from the tagged plants. Days taken for opening of first flower from planting was recorded by counting the days from the date 
of planting to the stage at which the first flower opened in each net plot from the tagged plants. Spikes were harvested from the plot at bud-burst stage when basal pair of florets was just opened. Length of the spike was measured when the spike was at exact stage to harvest and was taken from the point of spike emergence to the top most floret on spike.

The total number of bulbs and bulblets were counted after uprooting the clump except the mother bulb. Length of bulb was measured by using verniercaliper scale and it was taken along the longitudinal axis of the bulb from basal disc to tip. Diameter of the bulb was measured by a thread and the same was again measured by a scale and recorded in centimetres. Weighing of bulb has done by using electrical balance.

\section{Results and Discussion}

With respect to the vegetative characters, among the eleven treatments, $\mathrm{T}_{9}[75 \% \mathrm{~N}$ (Urea) $+25 \% \mathrm{~N}$ (Mustard oil cake)] showed highest plant height $(12.6 \mathrm{~cm})$, maximum number of leaves (45.6) at first flowering followed by treatment $\mathrm{T}_{8}[75 \% \mathrm{~N}$ (Urea) + $25 \% \mathrm{~N}$ (Vermicompost)] $(12.3 \mathrm{~cm})$ and the treatments showed results were statistically at par. Similar finding was reported by Pattanaik (2016) with respect to application of Vermicompost @ $1 \mathrm{Kg} / \mathrm{m}^{2}$ and Mustard oil cake@250g/m². Shankar et al., 2010; Kabir et al., 2011 and Munikrishnappa et al., 2011 noticed significantly higher plant height with application of vermicompost and 50\% RDF in tuberose. Highest leaf length $(91.91 \mathrm{~cm})$ was recorded in treatment $\mathrm{T}_{2}[(100 \% \mathrm{~N}$ (Vermicompost)] followed by treatment $\mathrm{T}_{9}$ [75\% N (Urea) $+25 \% \mathrm{~N}$ (Mustard oil cake)] $(86.7 \mathrm{~cm})$. The improvement in leaf length in tuberose with the application of organic manures was also reported by Shankar et al., 2010 and Kabir et al., 2011 in tuberose.
$\mathrm{T}_{9}[75 \% \mathrm{~N}$ (Urea) $+25 \% \mathrm{~N}$ (Mustard oil cake)] showed early emergence of spike (47.33 days) and it took 63.44 days for the opening of first flower from planting. Highest spike length $(122.81 \mathrm{~cm})$ was recorded in $\mathrm{T}_{9}$ [75\% N (Urea) + 25\% N (Mustard oil cake)].

These findings are well supported by the results obtained by Pattanaik (2016) with respect to application of Mustard oil cake @ $500 \mathrm{~g} / \mathrm{m}^{2}$ where the floral character like spike length was maximum as compared to other treatments and the days taken for first flower opening was also minimum. The highest number of spike per plot (79.6) was recorded in treatment $\mathrm{T}_{9}[75 \% \mathrm{~N}$ (Urea) $+25 \% \mathrm{~N}$ (Mustard oil cake)] followed by treatment $\mathrm{T}_{8}$ $[75 \% \mathrm{~N}$ (Urea) $+25 \% \mathrm{~N}$ (Vermicompost)] and the treatments were statistically at par.

This ultimately led to the highest flower yield per plot $(5.45 \mathrm{~kg})$ in the treatment $\mathrm{T}_{9}[75 \% \mathrm{~N}$ (Urea) $+25 \% \mathrm{~N}$ (Mustard oil cake)] followed by $\mathrm{T}_{8}[75 \% \quad \mathrm{~N}$ (Urea) $+25 \% \mathrm{~N}$ (Vermicompost)]. Mustard oil cake is a nutritive organic manure increases the level of macro and micro nutrients in soil and improves the level of growth promoting substances. As a result, their application stimulating the vegetative and reproductive growth of the plant. Mustard oil cake is an excellent source of nitrogen can replace not only the use of chemical fertilizers but also replace the use of pesticides by suppressing pathogens and insects (Bose et al., 1999).

Research works have shown that compost and other organic manures like farmyard manure, cocodust, water hyacinth, mustard oil cake, vermicompost etc. can serve as soil amendments to improve soil nutrient status, water holding capacity as well as increase vase life (Kabir et al., 2011). They also stabilize soil $\mathrm{pH}$, increase soil organic matter and ultimately improve plant growth and yield. 
Among the eleven treatments highest number of bulbs (18.6) was recorded in treatment $\mathrm{T}_{3}$ [100\% N (Mustard oil cake)] followed by treatment $\mathrm{T}_{6}[50 \% \mathrm{~N}$ (Urea) $+50 \% \mathrm{~N}$ (Mustard oil cake)] (17.3) which was statistically at par. Highest number of bulblets
(16.33) obtained from the treatment $\mathrm{T}_{10}$ [100\% N (Urea)]. Highest average length (7.8 $\mathrm{cm})$, diameter $(3.8 \mathrm{~cm})$ of bulb was recorded in treatment $\mathrm{T}_{6}[50 \% \mathrm{~N}$ (Urea) $+50 \% \mathrm{~N}$ (Mustard oil cake)].

Table.1 Effect of organic and inorganic sources of nitrogen on growth and yield of tuberose (Polianthes tuberosa) $\mathrm{cv}$. Prajwal on vegetative character and yield

\begin{tabular}{|c|c|c|c|c|c|c|c|c|c|}
\hline & Treatments & $\begin{array}{l}\text { Plant height at } \\
\text { first flowering } \\
\text { (cm) }\end{array}$ & $\begin{array}{l}\text { No of leaves at } \\
\text { first flowering }\end{array}$ & $\begin{array}{l}\text { Leaf } \\
\text { length } \\
(\mathrm{cm})\end{array}$ & $\begin{array}{c}\text { Days } \\
\text { taken for } \\
\text { emergence } \\
\text { of spike }\end{array}$ & $\begin{array}{c}\text { Days } \\
\text { taken for } \\
\text { opening } \\
\text { of first } \\
\text { flower } \\
\text { from } \\
\text { planting }\end{array}$ & $\begin{array}{c}\text { Number } \\
\text { of } \\
\text { spikes/Plot }\end{array}$ & $\begin{array}{l}\text { Spike } \\
\text { length } \\
\text { (cm) }\end{array}$ & 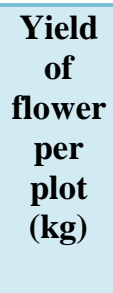 \\
\hline $\mathbf{T}_{\mathbf{0}}$ & Control & 9.4 & 31 & 70.4 & 53.3 & 68.3 & 32.3 & 100 & 1.5 \\
\hline $\mathbf{T}_{1}$ & $100 \%$ N (FYM) & 9.6 & 32.7 & 74.8 & 48 & 64.3 & 46.6 & 115 & 2.5 \\
\hline $\mathbf{T}_{2}$ & $\begin{array}{c}100 \% \mathrm{~N} \\
\text { (Vermicompost) }\end{array}$ & 9.8 & 34.1 & 91.91 & 48.3 & 64.6 & 53.3 & 106.03 & 2.93 \\
\hline $\mathbf{T}_{3}$ & $\begin{array}{c}100 \% \mathrm{~N} \\
\text { (Mustard oil } \\
\text { cake) }\end{array}$ & 9.9 & 35.5 & 86 & 48.3 & 64.4 & 53.6 & 110.4 & 2.9 \\
\hline $\mathbf{T}_{4}$ & $\begin{array}{l}50 \% \text { N (Urea) + } \\
50 \% \text { N (FYM) }\end{array}$ & 10 & 40.07 & 73 & 48 & 71.3 & 54.6 & 105.3 & 2.56 \\
\hline $\mathbf{T}_{5}$ & $\begin{array}{c}50 \% \mathrm{~N} \text { (Urea) + } \\
50 \% \mathrm{~N} \\
\text { (Vermicompost) }\end{array}$ & 10.03 & 42.03 & 86.4 & 54 & 71.7 & 57 & 102 & 3.6 \\
\hline $\mathbf{T}_{6}$ & $\begin{array}{c}50 \% \mathrm{~N} \text { (Urea) + } \\
50 \% \mathrm{~N} \\
\text { (Mustard oil } \\
\text { cake) }\end{array}$ & 10.3 & 44.3 & 83 & 55 & 79.8 & 64.6 & 104.5 & 3.9 \\
\hline $\mathbf{T}_{7}$ & $\begin{array}{l}75 \% \mathrm{~N} \text { (Urea) + } \\
25 \% \mathrm{~N}(\mathrm{FYM})\end{array}$ & 11 & 45.4 & 75.8 & 50 & 66.09 & 68.6 & 111.3 & 4.3 \\
\hline $\mathbf{T}_{8}$ & $\begin{array}{c}75 \% \mathrm{~N} \text { (Urea) + } \\
25 \% \mathrm{~N} \\
\text { (Vermicompost) }\end{array}$ & 12.3 & 45.5 & 85.5 & 48.6 & 66.2 & 75 & 104.1 & 4.6 \\
\hline $\mathbf{T}_{9}$ & $\begin{array}{c}75 \% \mathrm{~N} \text { (Urea) + } \\
25 \% \mathrm{~N} \\
\text { (Mustard oil } \\
\text { cake) }\end{array}$ & 12.6 & 43.6 & 86.7 & 47.3 & 63.4 & 79.6 & 123 & 5.45 \\
\hline$T_{10}$ & $100 \%$ N (Urea) & 10.8 & 43.4 & 77.1 & 50.6 & 69.6 & 65 & 110.4 & 3.9 \\
\hline & $\mathrm{SE}(\mathrm{m}) \pm$ & 0.39 & 2.17 & 1.025 & 1.31 & 0.88 & 5.9 & 0.85 & 0.33 \\
\hline & $\mathrm{SD}(\mathrm{P}=\mathbf{0 . 0 5})$ & 1.42 & 7.89 & 3.71 & 4.75 & 3.21 & 21.37 & 3.10 & 1.29 \\
\hline
\end{tabular}


Tabl.2 Effect of organic and inorganic sources of nitrogen on growth and yield of tuberose (Polianthes tuberosa) cv. Prajwal on Bulb characteristic

\begin{tabular}{|c|c|c|c|c|c|c|}
\hline \multicolumn{2}{|c|}{ Treatment } & \multirow{2}{*}{$\begin{array}{c}\begin{array}{c}\text { Number } \\
\text { of bulbs }\end{array} \\
9\end{array}$} & \multirow{2}{*}{$\begin{array}{c}\begin{array}{c}\text { Number of } \\
\text { bulblets }\end{array} \\
6.6\end{array}$} & \multirow{2}{*}{$\begin{array}{c}\begin{array}{c}\text { Length } \\
\text { of bulb } \\
\text { (cm) }\end{array} \\
5\end{array}$} & \multirow{2}{*}{$\begin{array}{c}\begin{array}{c}\text { Diameter } \\
\text { of bulb } \\
\text { (cm) }\end{array} \\
2.29\end{array}$} & \multirow{2}{*}{$\begin{array}{c}\begin{array}{c}\text { Weight } \\
\text { of bulb } \\
\text { (gm) }\end{array} \\
18.4\end{array}$} \\
\hline $\mathbf{T}_{\mathbf{0}}$ & Control & & & & & \\
\hline $\mathbf{T}_{\mathbf{1}}$ & $100 \%$ N (FYM) & 15 & 11.6 & 7.8 & 2.7 & 20.6 \\
\hline $\mathbf{T}_{2}$ & $\begin{array}{l}100 \% \mathrm{~N} \\
\text { (Vermicompost) }\end{array}$ & 11.3 & 12 & 7 & 2.9 & 31.7 \\
\hline $\mathbf{T}_{\mathbf{3}}$ & $\begin{array}{l}100 \% \text { N (Mustard oil } \\
\text { cake) }\end{array}$ & 18.6 & 15.3 & 8.16 & 3.2 & 32.1 \\
\hline $\mathbf{T}_{4}$ & $\begin{array}{l}50 \% \mathrm{~N}(\text { Urea })+50 \% \mathrm{~N} \\
(\mathrm{FYM})\end{array}$ & 10.3 & 10 & 6.3 & 3.6 & 28.4 \\
\hline $\mathbf{T}_{5}$ & $\begin{array}{l}50 \% \mathrm{~N} \text { (Urea) }+50 \% \mathrm{~N} \\
\text { (Vermicompost) }\end{array}$ & 13.3 & 15.6 & 6.7 & 2.7 & 32.6 \\
\hline $\mathbf{T}_{6}$ & $\begin{array}{l}50 \% \mathrm{~N}(\text { Urea) }+50 \% \mathrm{~N} \\
\text { (Mustard oil cake) }\end{array}$ & 17.3 & 11.6 & 7.8 & 3.8 & 36.7 \\
\hline $\mathbf{T}_{7}$ & $\begin{array}{l}75 \% \mathrm{~N} \text { (Urea) }+25 \% \mathrm{~N} \\
(\mathrm{FYM})\end{array}$ & 11.6 & 8.6 & 5.7 & 2.35 & 21.5 \\
\hline $\mathbf{T}_{8}$ & $\begin{array}{l}75 \% \mathrm{~N} \text { (Urea) + } 25 \% \mathrm{~N} \\
\text { (Vermicompost) }\end{array}$ & 12.3 & 8.6 & 5.4 & 2.57 & 22.6 \\
\hline $\mathbf{T}_{\mathbf{9}}$ & $\begin{array}{l}75 \% \mathrm{~N} \text { (Urea) }+25 \% \mathrm{~N} \\
\text { (Mustard oil cake) }\end{array}$ & 11.6 & 12.3 & 5.43 & 2.6 & 29.2 \\
\hline $\mathbf{T}_{10}$ & $100 \%$ N (Urea) & 14.6 & 16.3 & 6.05 & 2.7 & 31.3 \\
\hline \multicolumn{2}{|c|}{$\mathrm{SE}(\mathbf{m}) \pm$} & 0.95 & 1.2 & 0.175 & 0.072 & 0.28 \\
\hline \multicolumn{2}{|c|}{$\operatorname{LSD}(P=0.05)$} & 3.472 & 4.35 & 0.636 & 0.262 & 1.021 \\
\hline
\end{tabular}

Significantly highest total bulb weight $(36.72$ g) was also recorded in treatment $\mathrm{T}_{6}[50 \% \mathrm{~N}$ (Urea) $+50 \% \mathrm{~N}$ (Mustard oil cake)] followed by $32.64 \mathrm{~g}$ in treatment $\mathrm{T}_{5}[50 \% \mathrm{~N}$ (Urea) + 50\% N (Vermicompost)]. Similar findings were also reported by Pattanaik (2016) that the treatment (Vermicompost @ $1 \mathrm{Kg} / \mathrm{m} 2+$ Mustard oil cake@250g/ $\mathrm{m}^{2}$ ) recorded the maximum for bulb parameters like bulb length, bulb weight, bulb circumference and yield of the bulb compared to other treatments. The higher bulb parameters in organic fertilizers applied plants than chemical fertilizers might be produced more assimilate by greater number of leaves (Shankar et al., 2010 and Kabir et al., 2011) in tuberose. Nitrogen has a significant effect on bulb production of tuberose. These results are consistent with the result of Mazed et al., (2015) who reported that application of organic amendments with chemical fertilizers increased bulb yield.

Based on the result of the study it was concluded that application of organic manures obtained significant differences in vegetative, flower and bulb parameters of the plant. Among all the organic manures and their 
combinations, $75 \% \mathrm{~N}$ obtained from Urea and $25 \% \mathrm{~N}$ from Mustard oil cake exhibited well when vegetative parameters and flower parameters were considered compared to other treatments. But considering the bulb parameters best results shown by the combination of $50 \% \mathrm{~N}$ obtained from Urea and $50 \% \mathrm{~N}$ obtained from Mustard oil cake. As mustard oil cake is the rich source of Nitrogen, phosphorous and sulphur, use of this organic matter as manure and soil amendment may be advocated.

\section{References}

Bose, T.K., Maiti, R.G., Dhua, R.S. and Das, P., 1999, Tuberose. In: Floriculture and Landscaping. Nayaprakash, Calcutta, India.505-514.

Habib, Z.F.B., Hossain, M.I., Sultana, T. and Halim, A., 2016, Growth and yield of tuberose (Polianthes tuberosa L.) as influenced by nutrient management, European academic research, 3(12): 12784-12795.

Kabir, A.K.M.R., Iman, M.H., Mondal, M.M.A. and Chowdhury, S., 2011,
Response of tuberose to integrated nutrient management, Journal of Environmental Science and Natural Resources, 4(2): 55-59.

Mitra, M., 2010, Response of tuberose to integrated nutrient management, International conference on biodiversity, livelihood and climate change in the Himalaya, Department of Botany, Tribhuvan University, India.

Pattanaik, S., 2016, Effect of organic manures on growth and flowering of tuberose (Polianthes tuberosa L.) cv. Phulerajani. M.Sc. (Ag) Thesis.

Shankar Lal, Lakhawat, S.S. and Choudhary, M.K., 2010, Effect of organic manures and bio fertilizers on growth, flowering and bulb production in tuberose, Indian Journal of Horticulture, 64(4): 554-556.

Tripathi, S.K., Malik, S., Singh, I.P., Dhyani, B.P., Kumar,V., Dhaka, S.S. and Singh, J.P., 2012, Effect of integrated nutrient management in cut flower production of tuberose (Polianthes tuberosa L.) var. Suvasini, Annals of Horticulture, 5(1): 108-15.

\section{How to cite this article:}

Sukirti Mohanty, Manas Ranjan Nath and Sidhhath Kumar Palai. 2020. Effect of Organic and Inorganic Sources of Nitrogen on Plant Growth, Bulb Characteristics and Yield of Tuberose (Polianthes tuberose L.) cv. Prajwal. Int.J.Curr.Microbiol.App.Sci. 9(03): 1561-1566. doi: https://doi.org/10.20546/ijcmas.2020.903.183 